\title{
Six-Pointed Star Motif in Muslim Architecture of Bangladesh (Past Bengal) and Turkish Influence: An Historical Study ${ }^{\mathrm{I}}$
}

\author{
Sk. Zohirul Islam \\ Research Assistant \\ Center for Heritage Studies (CenHerSt), Dinajpur, Bangladesh \\ And \\ Curriculum Coordinator \\ Siddiqui's International School, Dhaka, Bangladesh \\ E-mail: zohirulbgsjpo@gmail.com
}

\begin{abstract}
With the rise of Islamic states as the dominant powers of India and Indian Sub- Continent (India, Pakistan and Bangladesh) and South Asia Sultanate and Mughal period (I200-I800 A.D.), by Turkish heroic figure (horsemen), Indian art was subjected to Islamic influence, resulting in a hybrid aesthetics as well as Indo- Islamic art which flourished to varying extends across south and southeast Asia. Bangladesh is world third largest Muslim majority country and situated in South Asia. So the main and primary identity of the notion is mosque architecture and then languages via culture in Bangladesh (past Bengal). Moreover, Traditional history called Mughal and ottoman was the center of all traders and referred as the "Middle Man" due to access to water routes between Asia and Europe. The Ottoman and Mughal Empires were all founded with art and architecture by members of the same ethnically Turkic tribe and originated from Oghuz tribe. Firstly, in the early I4th century, Osman Bey established a small principality in the northeast corner of Anatolia. Despite these many similarities, there are some key difference within the approach to Islamic Art and Architecture from Miniatures Illustrations in Indian Sub-Continent to Mosque architecture in Turkey and the Levant the Mughal and Ottoman empires left their indications. Turkish Military Ikhtiyar Uddin bin Muhammad Bhaktiyer Khilji and his Turkish followers captured Bengal in I204 A.D. and after then ruled by Turkic. Besides these many Sufis saint-like Khan Jahan Ulugh Khan, Burhan Khan, Gharib Shah, came here and spread Islam and Turkish culture with languages too. The Ilyas Shahi dynasty was the first independent Turkic Muslim ruling dynasty in late medieval Bengal, which ruled from the I4th century to the I5th century. It was founded in I342 by Shamsuddin Iliyas Shah. As follows still presence many Turkish words which used in the Bengali language as Barood, Nishan, Chaku, Bahadur, Begum, Chadar, Surma, bavarchi, kiyma, Korma, and so on. And then showed their power through art and architecture as Mosques and Tombs follows Adina Masjid at Pandua in I368 A.D.; Eklakhi mausoleum, Pandua; Tomb of Shah Rukn-e Alam in Multan, Sixty Domed Mosque at Bagherhat of Bangladesh, etc. Based on all evidence present, it can be found that the Turks contributed significantly to Bengali languages and culture as well as art and architecture (Mosques and Tombs). Besides many Jewish people came in here through missionary and business purposes. And also we see that there have been found many designs in mosque architecture especially six-point stars which is mentioned as a David symbol. So my focus is the Connectivity between Turkish and Bangladesh through Islamic architecture and Jewish with six point star/hexagon/seal of Solomon. It is a historical study with a journalistic approach.
\end{abstract}

Keywords: Six-Pointed Star, Bangladesh, Jewish, Architecture, Connections, Mediaeval Period, Turkish.

\begin{abstract}
I. Introduction
With the rise of Islamic states as the dominant powers of India and Indian Sub- Continent (India, Pakistan and Bangladesh) and South Asia Sultanate and Mughal period $13^{\text {th }}$ and $18^{\text {th }}$ century, by Turkish heroic figure as horsemen, Indian art was subjected to Islamic influence, resulting in a hybrid aesthetics as well as Indo- Islamic art which flourished to varying extends across south and southeast Asia. Among Officially the People's Republic of Bangladesh is world $3^{\text {rd }}$ largest Muslim majority country and situated in South Asia. It shares land borders with India and Myanmar. The country's maritime territory in the Bay of Bengal in the southern part of its. Dhaka is its capital and largest city. Islam is the official religion of Bangladesh. So the main and primary identity of the notion is mosque architecture and then languages via culture in Bangladesh (past Bengal). Besides many Jewish
\end{abstract}

${ }^{1}$ Published in the proceedings of Second International Conference on Israel and Judaism Studies (ICIJS)-2018 at Turkey. 
people came in here through missionary and business purposes from Mughal Emperor Jahangir's. And also we see that there have been found many designs in mosque architecture especially the six-pointed star motif which is mentioned as David symbol and seal or signet of Solomon. So my focus is the Connectivity between Turkish and Bangladesh through Islamic architecture and Jewish with six-pointed star/hexagon/seal of Solomon. It is a preliminary historical study with a journalistic approach.

\section{Background}

Bangladesh Geography Bangladesh covers an area of $147,570 \mathrm{sq} \mathrm{km}$. It extends from 20'34N to 26 '38N latitude and from 88'0IE to 92'4IE longitude. The Indian States of West Bengal, Assam, Meghalaya and Tripura border Bangladesh in the west, north, and east respectively. Myanmar forms the southern part of the eastern frontier. The total length of the land border is about $4,246 \mathrm{~km}$, of which $93.9 \%$ is shared with India and about $6.1 \%$ with Myanmar. The country is bounded in the south by the Bay of Bengal. Although the length of the coastline is more than $580 \mathrm{~km}$. The territorial waters of Bangladesh extend 12 nautical miles $(22.22 \mathrm{~km})$ and the area of the high seas extending to 200 nautical miles $(370.40 \mathrm{~km})$ measured from the baselines constitutes the economic zone of the country. Bangladesh is fringed on the southwest by the huge expanse of mangrove forest known as the Sundarbans, the abode of the famous Royal Bengal Tiger (Banglapedia, 2004).

\section{Six-pointed star symbol used in Bangladesh Architecture}

Six-Pointed star depicted as motif in Muslim Architecture of Bangladesh as follows:

- Moazzampur Shahi Mosque, Sonargaon, Narayanganj, I43I/32 A.D. Sultanate era.

- Baba Adam Mosque, Munshiganj, Sultanate era.

- Bajra Shahi Mosque, Begumganj, Noakhali, I74I/42 A.D. Mughal era.

- Sarail Bridge, Sarail, Brahmanbariya, Mughal era.

- $\quad$ Arifail Mosque, Sarail, Brahmanbariya, late $17^{\text {th }}$ Century, Mughal era.

- Laldighi Mosque, Badarganj, Rangpur, late I $^{\text {th }}$ Century, Mughal era.

- Sitara Mosque, Armanitola, Old Dhaka, I9 ${ }^{\text {th }}$ Century, Mughal era.

3.I Moazzampur Shahi Mosque: Moazzampur Shahi Mosque is situated in Sonargaon (past it was a capital city of Bengal during Sultanate period) under Narayanganj district of Bangladesh in I43I/32 A.D. it is remaining early Sultanate era architecture built reign of Shams Al-din-Ahamad Shah. Here we have seen this motif used in the Meherab.

3.2 Baba Adam Mosque: Baba Adam Mosque, Munshiganj, Sultanate era. Here we have been found the same decoration as Moazzampur Shahi Mosque of Bangladesh.

3.3 The Bajra Shahi Mosque: The Bajra Shahi Mosque (Photo I \& 2) is situated at Begumganj Upazila in Noakhali district of Bangladesh and dated I74I/42 A.D (recorded by inscription II54 A. H.) during the reign of Muhammad Shah and builder name is Amanullah.

3.4 Sarail Bridge: Sarail Bridge (Photo 4), Sarail Upazila, Brahmanbariya district, Mughal era: - here on the spandrel of the arch medallion designs are found where used six-pointed star with flower-shaped.

3.5 Arifail Mosque: Arifail Mosque (Photo 5) is situated Sarail Upazila under the Brahmanbariya district. It is built by saint shah Arif in the late $17^{\text {th }}$ century. It is a three-domed Mughal Mosque. Here we have been found in the central doorway which shows an outward projection and internally embellished with the squinch nets and with hexagram or six-pointed star.

3.6 Laldighi Mosque: Laldighi Mosque (Photo 6) is situated in the village of Mougacha under Badarganj Upazila of the Rangpur district. The mosque was built in circa late $17^{\text {th }}$ century. The Central entrance archway has been found plastered decoration through six-pointed star similar Arifail Mosque.

3.7 Sitara mosque: Sitara mosque (Photo 7), Armanitola, Old Dhaka, I9 ${ }^{\text {th }}$ Century, Mughal era. It is built by Mirza Ghulam Pir first half of the $19^{\text {th }}$ century, generally, called Tara Masjid (star mosque), Here we wonderfully have been found all dome decorated by several blue color stars.

\section{Turkey Influence}

Moreover, Traditional history called Mughal and ottoman was the center of all traders and referred to as the "Middle Man" due to access to water routes between Asia and Europe. Actually, The Ottoman and Mughal Empires were all founded with art and architecture by members of the same ethnically Turkic tribe and originated from the Oghuz tribe. Firstly, in the early I4th century Osman Bey established a small principality in the northeast corner of Anatolia. Despite these many similarities, there are some key difference within the approach to Islamic Art and Architecture from Miniatures Illustrations in Indian Sub-Continent to Mosque architecture in Turkey (Photo I2) and the Levant the Mughal and Ottoman empires left their indications. Turkish Military Ikhtiyar-Uddin-bin Muhammad Bhaktiyer Khilji and his Turkish followers captured Bengal in I204 A.D. and after then ruled by Turkic. Besides these many Sufis saint-like Khan Jahan Ulugh Khan, Burhan Khan, came here and spread Islam 
and Turkish culture with languages too. The Ilyas Shahi dynasty was the first independent Turkic Muslim ruling dynasty in late medieval Bengal, which ruled from the I4th century to the I5th century. It was founded in I342 by Shamsuddin Iliyas Shah. As follows still presence many Turkish words which used in the Bengali language as Barood, Nishan, Chaku, Bahadur, Begum, Chadar, Surma, bavarchi, Kebab, kiyma, Korma, and so on. And then showed their power through art and architecture as Mosques and Tombs follows Adina Masjid at Pandua in 1368 A.D.; Eklakhi mausoleum, Pandua; Tomb of Shah Rukn-e Alam in Multan, Sixty Domed Mosque at Bagherhat of Bangladesh, etc. Based on all evidence present, it can be found that the Turks contributed significantly to Bengali languages and culture as well as Mosques and Tombs architecture.

\section{Six-pointed star Symbol and its meaning}

There have many type of the Six-Pointed Star Motif shape as follows: Hexagonal, Polygon, Pentagonal, Five-pointed star, Seal of Solomon, Star of David. Besides, many religion used it's like Islam, Christian, Judaism, Hinduism, Buddhism, Occultism. The Star of David is a six-pointed star or hexagram. It is the universal symbol for Judaism today, but only became aligned with Judaism in the 17th century when Jewish houses of worship were identified by placing the hexagram outside. In I897 the hexagram was adopted by the Zionist movement for a Jewish homeland and today the star graces Israel's flag (Photo I0). The six-pointed star is a common symbol throughout many different religions, including Islam. Muslims know the hexagram as the Seal of Solomon -- both Solomon and David were prophets, and both are mentioned in the Islamic holy book, the Quran. The hexagram appears in Islamic artifacts and mosques worldwide. A crescent moon and five-pointed star appear on the flags of Muslim-majority countries like Pakistan and Turkey. The symbols decorated mosques for centuries.

\section{Jewish connection}

There is no official diplomatic relationship between Bangladesh and Israel. Yet, the history of the Jewish community in Bangladesh dates back to the I7th-century. Very few Jews from Iran and Iraq settled in East Bengal (present Bangladesh) in the I800s in what was then British India (Zetler, 20II). Shalom Cohen (I762-I836) founded the Calcutta Jewish community in West Bengal and also the East Bengal Jewish community. They included a Baghdadi Jewish merchant community that settled in Dhaka during the 17th-century (Weil, 2015). The Jewish population in East Bengal was only about I35 Jews (Weil, 2012) at the time of the Partition of British India in 1947. By the late 1960s, much of the Jewish community had left for Calcutta. Members of the Bene Israel community from Bombay (today Mumbai) also resided in Dhaka in the I960s. The Jews in East Pakistan (Bangladesh in Pakistan period 1947-197I) were never numerous and kept a very low profile in this Muslim country. It is assumed that a few Jews remain, but they are quite assimilated. There is no synagogue today in Bangladesh. In research, Dr. Shalva Weil found that two families of Jewish descent do still live in Dhaka, but they have converted to Catholicism (Weil, 20I2). We need further research about this matter.

\section{Comparative Study}

This is very imprecise to say that there have been found Eight Muslim Architecture in Bangladesh where used a six-pointed star motif with decoration but no connection with Jewish or Star of David because there have no direct documents about this fact. Although after Emperor Jahangir's, some Jesuit people came with Portuguese and Armenian but they were just businessmen and in Bangladesh's perspective that was very little trade work. Bangladeshi continues to hold state policy of demonizing Israel and the country maintains a total ban on the Jewish state for decades. Travel by any Bangladeshi citizen to Israel is seen as an offense according to Bangladeshi law. Although Ironically, a Jewish architect from Philadelphia, Louis Kahn, designed the most important building in East Pakistan, the Jatiyo Sangsad Bhaban (Photo 15), the National Assembly building. Ranked as the world's largest legislative complex, this National Assembly was begun in I96I and was only completed in I982, eight years after Kahn's death. In I97I, the Bangladesh Liberation War took place. Interestingly, it was another famous Jew, Lieutenant General J F R Jacob, who liberated East Pakistan during this war. General Jacob, as he is known, was formerly governor of the Punjab and Goa. He was born into a Baghdadi Jewish family in Calcutta, and never hid his Jewish ancestry. In Seljuk or Ottoman mosque there are some geometric patterns based on constructive polygons, such as the hexagon and octagon. One of them is Star/ Shield of David or Solomon's Seal (نجمة/مجن داوود و خاتم سليمان) (dergipark.gov.tr). "the Seal of Solomon was used by Muslims from India to Spain to adorn and decorate the bottom of drinking vessels, coins issued by various dynasties, decorations on mosques and other buildings, and elsewhere. We have seen the same decoration in Mughal Architecture as Tomb of Humayun at Agra of India (Photo 9), Tomb of Itim-Ud- Daula at Agra of Delhi (Photo I3), Shah Mosque at Isfahan in Iran (Photo I4) and so on.

\section{Concluding Remarks}

The hexagram was not always an exclusively Jewish symbol, apart from the last century and a half. It was used by many cultures, including Arab and Islamic ones. Islamic decoration, which trends to avoid using figurative images according to the holy Quran, makes frequent use of geometric patterns that have developed over the centuries by Muslims. This is a preliminary study survey 
on the Connectivity between Turkish and Bangladesh through Islamic architecture and Jewish with a six-pointed star symbol as well as its characteristics features revisited with a journalistic approach. We have to need more research about this matter for clear understanding.

\section{References}

Banglapedia. (2004). A National Encyclopedia of Bangladesh, 2004, Sirajul Islam (Ed.), Asiatic society of Bangladesh, Dhaka.

Weil, S. (20I5). The extraordinary story of the Bangladesh Jews. The Jewish Chronicle. London. Archived from the original on 2015-I0-I6. Retrieved 2016-03-08.

Weil, S. (2012). The Unknown Jews of Bangladesh. Asian Jewish Life (I0). Retrieved 2016-03-08.

Zetler, D. (20II). Bangladesh - with Jewish connections. The Jerusalem Post. Archived from the original on 20I6-03-04. Retrieved 2016-03-08.

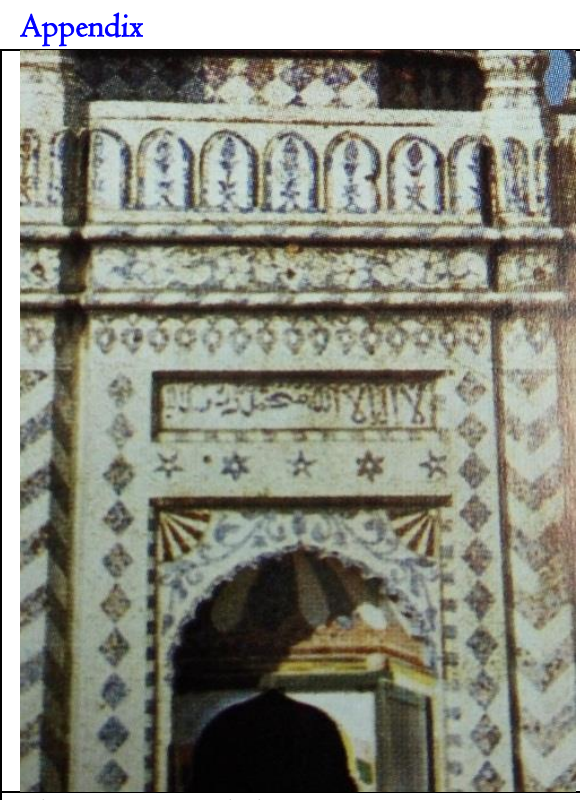

Photo I: Bajra Shahi Mosque, Begumganj, Noakhali, I74I/42 A.D. courtesy: after Hasan, S M

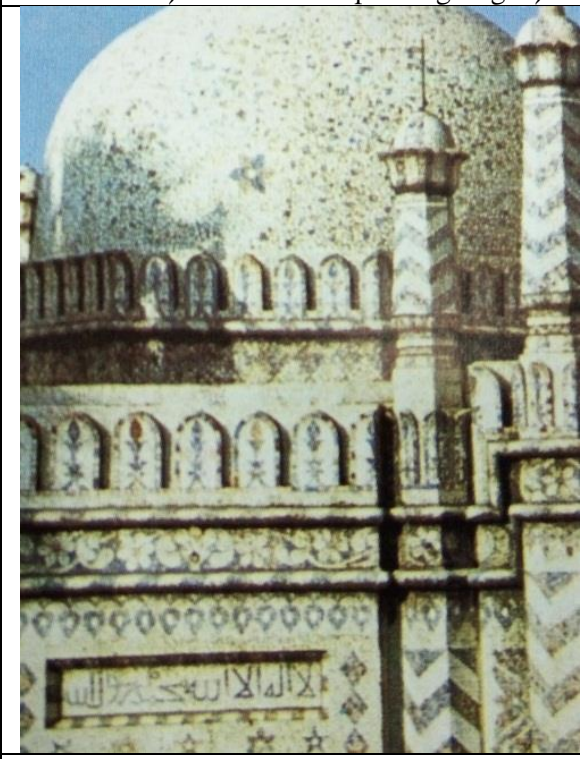

Photo 2: Bajra Shahi Mosque, Begumganj, Noakhali, I74I/42 A.D. courtesy: Babu 

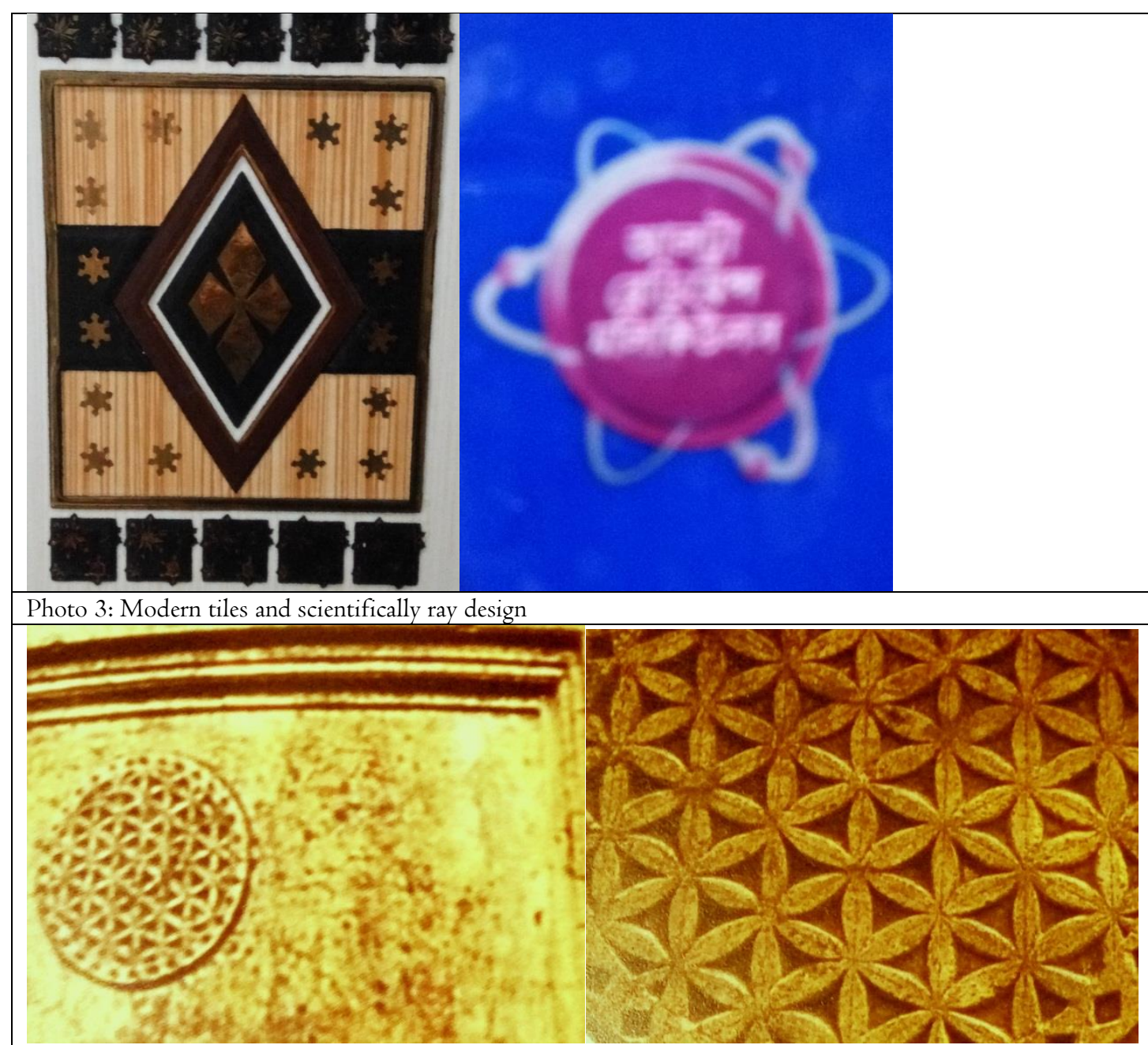

Photo 4: Sarail Bridge, Sarail, Brahmanbariya, Mughal era, courtesy: Babu

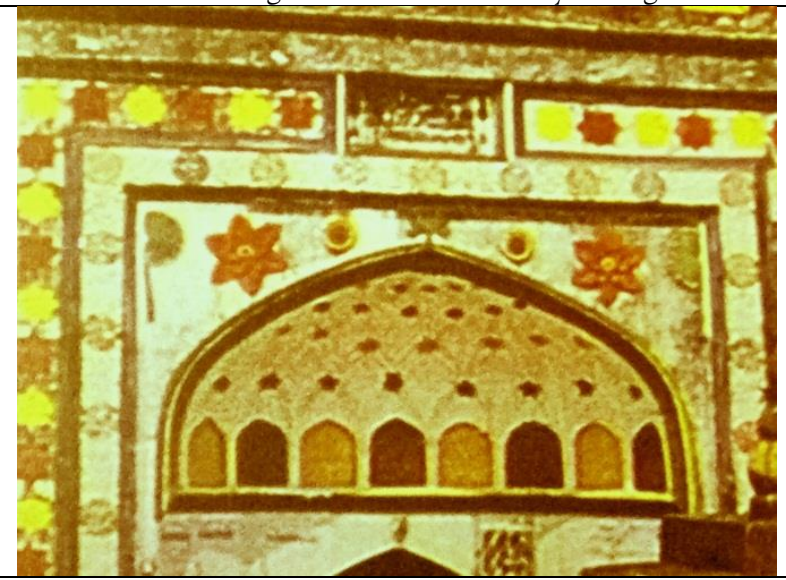

Photo 5: Arifail Mosque, Sarail, Brahmanbariya, late I7 ${ }^{\text {th }}$ century, courtesy: Babu 

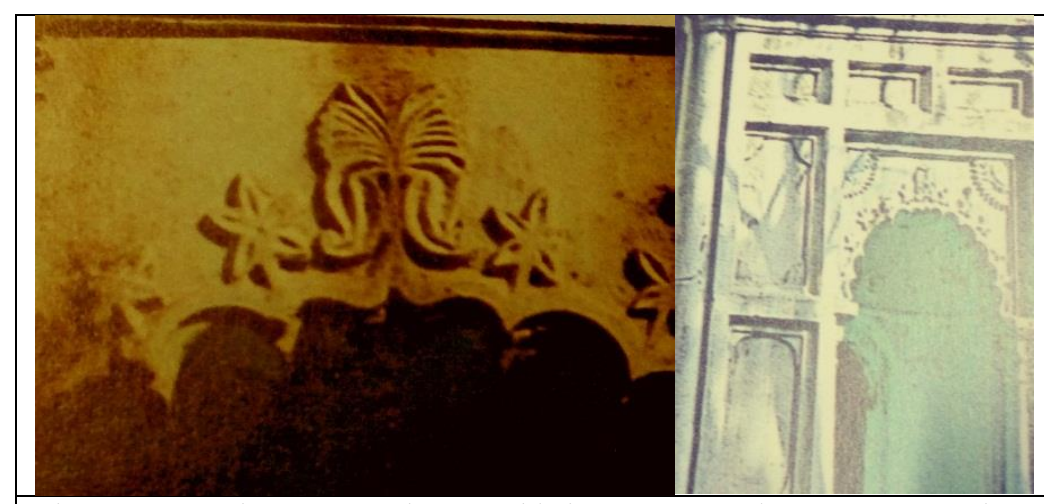

Photo 6: Central entrance archway, Laldighi Mosque, Badarganj, Rangpur, late $17^{\text {th }}$ century, courtesy: Babu

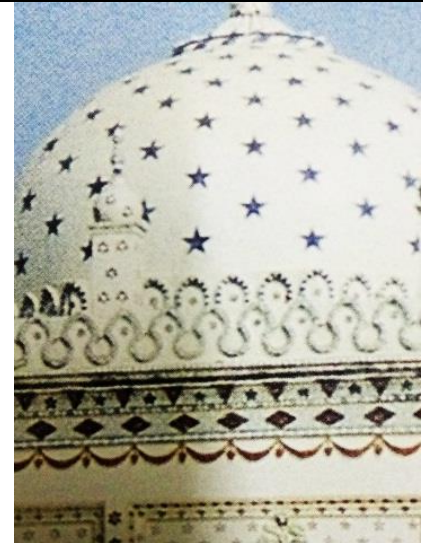

Photo 7: Dome, Sitara Mosque, Armanitola, Old Dhaka, courtesy: Babu

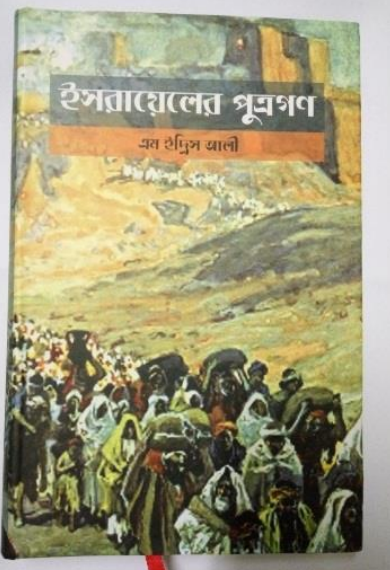

Photo 8: First book publication in 2013 at Bangladesh, Bengali language 


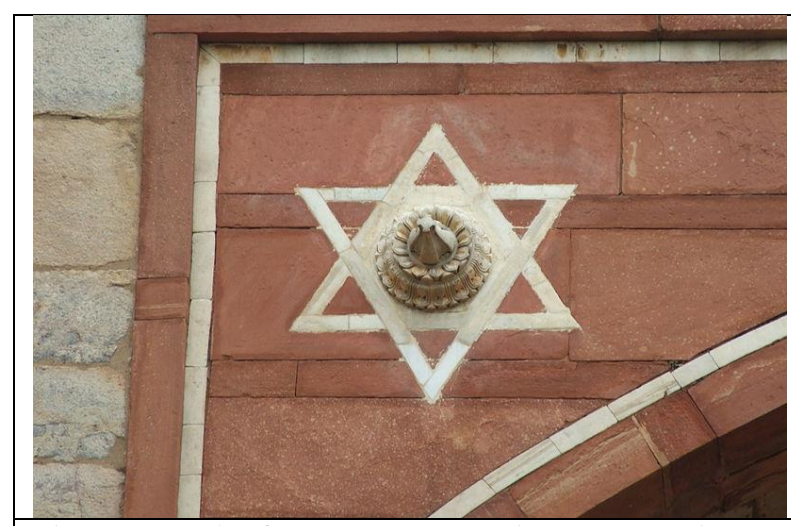

Photo 9: Tomb of Humaun, Agra, India, courtesy: Photo taken from Internet

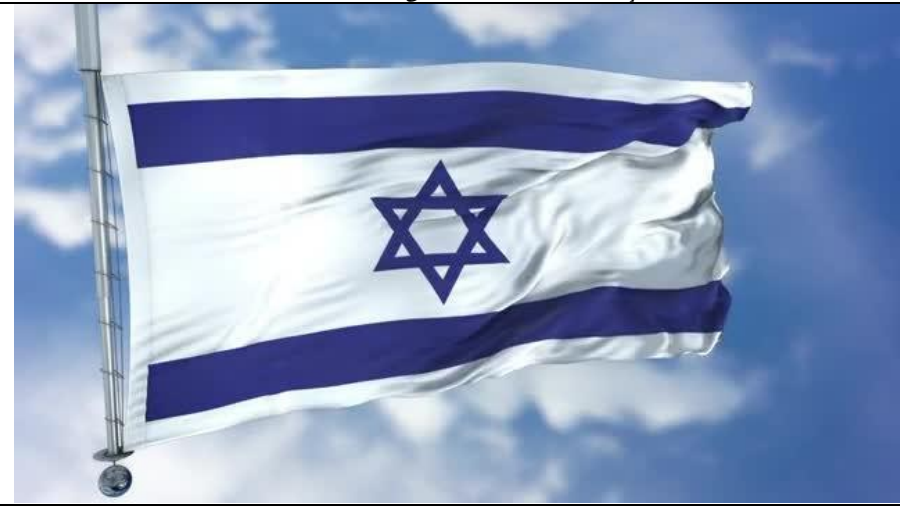

Photo I0: Flag of Israel, used six pointed star symbol, courtesy: Photo taken from Internet

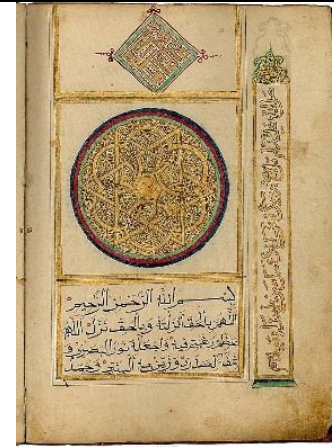

Photo II: Decorated Quran through hexagon, courtesy: Photo taken from Internet

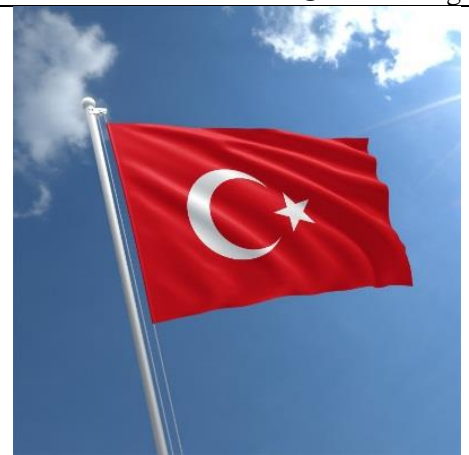

Photo I2: Turkey Flag, courtesy: Photo taken from Internet 

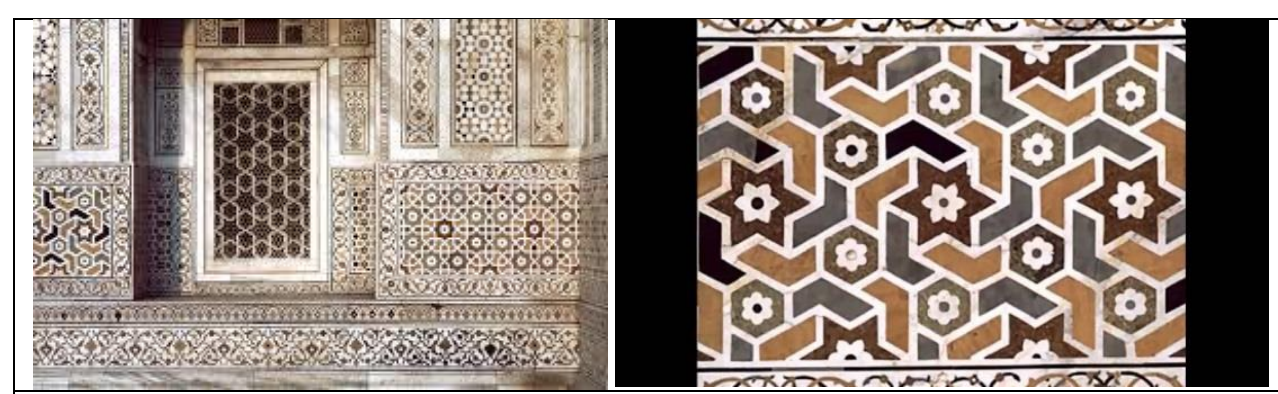

Photo I3: Tomb of Itimud-ud-Daula, Agra, India, courtesy: Photo taken from Internet

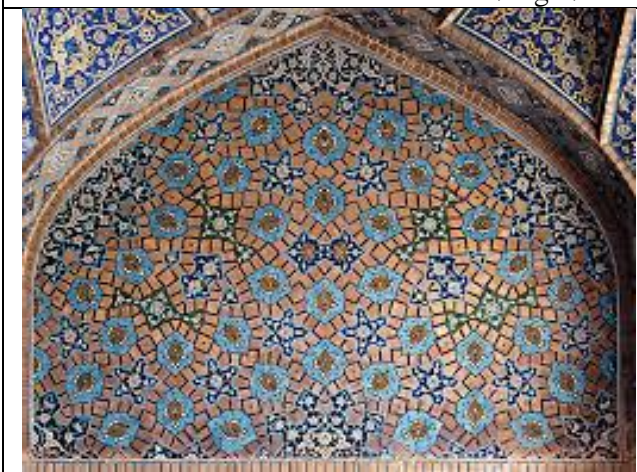

Photo I4: Shah Mosque, Isfahan, Iran, courtesy: Photo taken from Internet

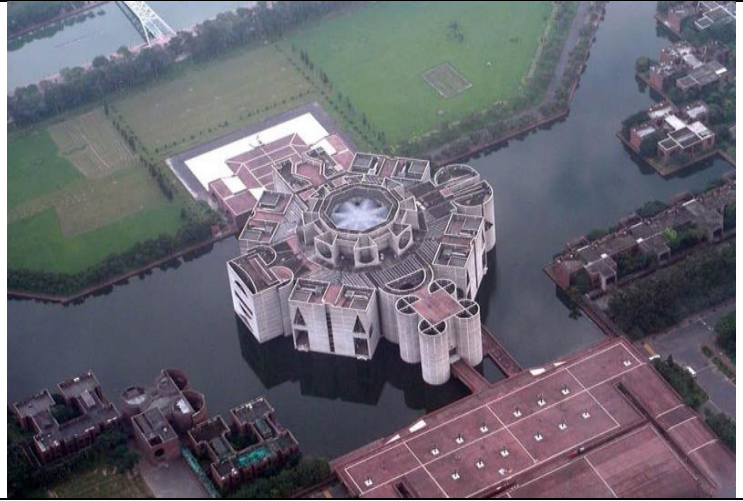

Photo I5: Jatiyo Sangsad Bhavan,(The National Parliament House) Dhaka, Bangladesh, courtesy: Photo taken from Internet

\section{Copyrights}

Copyright for this article is retained by the author(s), with first publication rights granted to the journal. This is an open-access article distributed under the terms and conditions of the Creative Commons Attribution license (http://creativecommons.org/licenses/by/4.0/). 